\title{
The use of legume and herb forage species to create high performance pastures for sheep and cattle grazing systems
}

\author{
Peter David Kemp ${ }^{1}$, Paul Richard Kenyon ${ }^{1}$, Stephen Todd Morris ${ }^{1}$ \\ ${ }^{1}$ Massey University, Palmerston North, New Zealand.
}

ABSTRACT - Sheep and cattle farmers need pastoral systems that are more productive and environmentally sustainable. The role that high feeding value herb and legume forage species can play in the farms of the future is highlighted. It is shown that species such as chicory (Cichorium intybus), plantain (Plantago lanceolata), red clover (Trifolium pratense) and white clover (T.repens) can provide live weight gains in lambs that are $70 \%$ greater than those from perennial ryegrass (Lolium perenne) based pastures. A case for replicated experiments that examine the value of whole technology packages based on herb and legume species, rather than component research, is made.

Key Words: chicory, feeding value, lamb growth, plantain, red clover, white clover

\section{Uso de leguminosas e forrageiras herbáceas para criar pastos de alto desempenho para sistema de pastejo de ovinos e bovinos}

\begin{abstract}
RESUMO - Produtores de ovinos e bovinos necessitam de sistemas pastoris mais produtivos e ambientalmente sustentáveis. As espécies forrageiras herbáceas e leguminosas de alto valor nutricional podem ter um papel destacado no futuro desses produtores. Foi demonstrado que espécies tais como a chicória (Cichorium intybus), plantago (Plantago lanceolata), trevo vermelho (Trifolium pratense) e trevo-branco (T. repens) podem fornecer um ganho de peso $70 \%$ maior em carneiros quando comparado com pastagens de azevém (Lolium perenne). Mais que um componente de pesquisa, este é um caso para repetidos experimentos que examinem o valor de todos os pacotes tecnológicos baseados em espécies herbáceas e leguminosas.
\end{abstract}

Palavras-chave: chicória, crescimento de ovelhas, plantago, trevo vermelho, trevo branco, valor alimentar

\section{Introduction}

Sheep and cattle farmers face financial, production and environmental challenges as they develop their farms into the future. Future pastoral livestock systems need forage species that will assist farmers to meet these challenges. Such forage species need to enable high animal intakes and to provide environmental advantages if targets such 200\% lambing, 300 plus g/day lamb live weight gains and mating of all ewe hoggets at heavier than $40 \mathrm{~kg}$ live weight are to be approached. Currently, there are temperate legume and herb forage species available with the attributes required to develop more productive and environmentally sustainable pastoral livestock systems but these systems have not been comprehensively demonstrated to farmers and consequently have not been widely adopted.

This paper presents the case for incorporating currently available high feeding value forage species into pastoral systems so sheep and cattle farmers can meet the challenges of the future. The focus is on realising the potential of currently available technology while plant breeders and molecular biologists pursue future breakthroughs.

Feeding value

The key to higher lamb and cattle live weight gains than possible on perennial ryegrass (Lolium perenne L.) and white clover (Trifolium repens L.) pastures, or on hill pastures, is to use forage species with higher feeding values. Feeding value is animal production when grazing on a forage is unrestricted, and incorporates voluntary feed intake and nutritive value per unit of dry matter (DM) eaten (Barry, 1998). Table 1 shows the feeding value for a range of pasture species. Clearly, some legume and herb species provide higher feeding value than perennial ryegrass or hill pasture species such as browntop (Agrostis capillaris L.). Although the presence of while clover increases the feeding value of perennial ryegrass and white clover pastures it is difficult to maintain a sufficient percentage of white clover when lambs are 
Table 1 - Feeding value of temperate pasture species based on live weight gain when fed ad libitum to growing lambs. Ranking is relative to white clover (100) (Waghorn et al., 2007)

\begin{tabular}{lcc}
\hline Specie & Ranking & N. Trials \\
\hline White clover & 100 & 15 \\
Chicory (Cichorium intybus) & 95 & 1 \\
Lotus corniculatus & 87 & 4 \\
Lotus pedunculatus & 84 & 6 \\
Tetraploid ryegrass (Lolium multiflorum) & 83 & 1 \\
Alfalfa (Medicago sativa) & 82 & 12 \\
Red clover (Trifolium pratense) & 70 & 7 \\
Timothy (Phleum pratense) & 67 & 5 \\
Perennial ryegrass & 52 & 16 \\
Browntop (Agrostis capillaris) & 46 & 2 \\
\hline
\end{tabular}

being grazed for finishing (Lindsay et al., 2007). The lax grazing required for maximum intakes by lambs allows them to preferentially select white clover. The average percentage of white clover in New Zealand hill pastures is $5 \%$ (Nicholas et al., 2004) and older lowland pastures are rarely more $10 \%$ white clover (Brock \& Hay 2001), whereas the optimum for lamb live weight gains is at least 70\% (Parsons et al., 1994).

Legume and herb species with high feeding values have consistently been found to enable summer lamb growth rates of $250 \mathrm{~g}$ live weight per day (Table 2) in contrast to the New Zealand average of $150 \mathrm{~g}$ /day at best (Kerr, 2000). Average lamb growth rates on pure perennial ryegrass or on browntop pastures are typically 80-150 g live weight/day (Kerr, 2000; Bluett et al., 2001). Lambs grown to their slaughter weight more quickly eat less feed in total than lambs grown slowly and so use the feed more efficiently. A consequence of this efficiency is that less methane is released per unit weight gain by the lambs (Waghorn et al., 2002). The feed saved can be allocated to ewe lambs and ewes to ensure their live weight is optimum for breeding. Alternatively, the feed can be used to finish more lambs or to increase cattle growth rates. If as a result of lax grazing by fast growing lambs the herb and legume pasture increases its proportion of stem and old leaf then it can be grazed with cattle. Bulls and calves have been found to produce live weight gains on maturing chicory ( $48 \%$ stem and $27 \%$ live leaf) that are equivalent to their gains on perennial ryegrass and white clover (Clark et al., 1990).

Table 2 shows that in ten experiments, in either New Zealand or United Kingdom, legume and herb forage species produced greater lamb live weight gains than perennial ryegrass, either tetraploid or diploid, with or without white clover. Although lamb growth rates were affected by variations in weather, it is apparent that either a combination of chicory, plantain, red clover and white clover, or chicory, red clover and white clover separately were able to support average lamb live weight gains of approximately $250 \mathrm{~g}$ live weight/day. In contrast, the average for the various combinations of ryegrass based pastures was approximately $150 \mathrm{~g}$ live weight/day.

Legume and herb forage species with high feeding value have also been shown to increase ewe and lamb productivity from lambing to weaning. The production of twin and triplet bearing/lactation ewes and their lambs grazing on a mix of chicory, plantain, red clover and white clover was compared with grazing on perennial ryegrass and white clover pasture (Kenyon \& Hutton, pers.comm.). At 66 days after lambing, ewes on the legume and herb pasture relative to the ewes on the ryegrass and white clover pasture were heavier (70.9 vs $66 \mathrm{~kg}$ ), were in better condition ( 2.8 vs 2.4 condition score), produced more milk (3237 vs $2428 \mathrm{ml}$ at day 21), and produced heavier lambs (20.7 vs 17.6 kg) (Kenyon \& Hutton, pers. Comm.). In total, the triplet bearing ewes on the legume and herb pasture produced a lamb weight of $45.7 \mathrm{~kg}$ at 66 days after lambing whereas those on the ryegrass and white clover pasture produced $28.3 \mathrm{~kg}$. In a separate experiment on the same pasture treatments the survival of lambs born to multiplebearing ewes sired by a Romney was better ( 97.8 vs $61.7 \%$ ) on the legume and herb pasture than the ryegrass and white clover pasture. However, there was no difference in lamb survival of Suffolk sired lambs so further research is needed for certainty on this effect.

For farmers the finishing of all lambs at a marketable target weight in the shortest possible time is important as it avoids needing to carry a group of slow growing lambs into late autumn and winter. The high feeding value of the herb and legume forage species results in a distribution of lamb growth rates skewed towards high growth rates as opposed to the normal distribution of lamb growth rates on ryegrass and white clover (Table 3 ).

Table 3 shows that there were very few poor performing lambs on the herb and legume pasture as well as the average live weight gain of lambs being greater than for ryegrass and white clover pasture (see Golding et al., 2008; Wilson, 2009 in Table 2).

The greater feeding value of herb and legume forage species results from both greater voluntary intake and greater nutritive value than perennial ryegrass (Barry, 1998). The organic matter digestibility (OMD) and metabolisable energy (ME) are higher and the neutral detergent fibre (NDF) is lower for herbs and legumes than perennial ryegrass. For example, in the experiment by Golding et al. (2008) in Tables 2 and 3 the OMD, ME and NDF of the herbs 
Table 2 - Live weight gains over summer of lambs grazing legume and/or herb species in comparison with ryegrass or ryegrass and white clover

\begin{tabular}{|c|c|c|}
\hline Forage specie & Live weight gain (g/day) & Reference \\
\hline Chicory/plantain/white & 247 & Golding et al. (2008) \\
\hline \multicolumn{3}{|l|}{ Clover/red clover } \\
\hline Tetraploid perennial & 119 & \\
\hline \multicolumn{3}{|l|}{ Ryegrass/white clover } \\
\hline Chicory/plantain/white & 246 & Wilson (2009) \\
\hline \multicolumn{3}{|l|}{ Clover/red clover } \\
\hline Tetraploid perennial & 56 & \\
\hline \multicolumn{3}{|l|}{ Ryegrass/white clover } \\
\hline White clover & 269 & Lindsay et al. (2007) \\
\hline Leaf turnips & 245 & \\
\hline Tetraploid perennial & 226 & \\
\hline \multicolumn{3}{|l|}{ Ryegrass/white clover } \\
\hline Birdsfoot trefoil & 258 & \\
\hline Perennial ryegrass/white & 189 & Restrepo et al. (2002) \\
\hline \multicolumn{3}{|l|}{ Clover } \\
\hline Chicory & 280 & Scales et al. (1995) \\
\hline Alfalfa & 236 & \\
\hline Perennial ryegrass & 158 & \\
\hline Plantain & 222 & Moorhead et al. (2002) \\
\hline Perennial ryegrass/white & 135 & \\
\hline \multicolumn{3}{|l|}{ Clover } \\
\hline Chicory & 290 & Fraser et al. (1988) \\
\hline Perennial ryegrass/white & 150 & \\
\hline \multicolumn{3}{|l|}{ Clover } \\
\hline White clover & 226 & Fraser \& Rowarth (1996) \\
\hline Chicory & 192 & \\
\hline Perennial ryegrass & 121 & \\
\hline White clover & 282 & Marley et al. (2005) \\
\hline Red clover & 292 & \\
\hline Alfalfa & 210 & \\
\hline Perennial ryegrass & 201 & \\
\hline Red clover & 305 & Fraser et al. (2004) \\
\hline Alfalfa & 243 & \\
\hline Perennial ryegrass & 184 & \\
\hline
\end{tabular}

Table 3 - The percentage (\%) of lambs growing slower than $100 \mathrm{~g}$ live weight/d or faster than $200 \mathrm{~g} / \mathrm{d}$ on a herb and legume pasture (plantain, chicory, red clover, white clover) or a tetraploid perennial ryegrass and white clover pasture (Golding et al., 2008)

\begin{tabular}{lcccc}
\hline Experiment & Pasture treatment & $\leq 100 \mathrm{~g} / \mathrm{d}$ & 87 \\
\hline 1 & Herb/legume & 0 & $200 \mathrm{~g} / \mathrm{d}$ \\
& Ryegrass/clove & 3 & 71 \\
& Herb/legume & 76 & 0 \\
\hline
\end{tabular}


and legumes pasture were $829 \mathrm{~g} / \mathrm{kg}$ DM, $11.4 \mathrm{MJ} / \mathrm{kg}$ DM and $281 \mathrm{~g} / \mathrm{kg}$ DM, respectively, compared with $641 \mathrm{~g} / \mathrm{kg} \mathrm{DM}$, $9.0 \mathrm{MJ} / \mathrm{kg}$ DM and $481 \mathrm{~g} / \mathrm{kg}$ DM, respectively, for perennial ryegrass and white clover pasture. Nevertheless, to provide the higher feeding value to sheep and cattle it is essential that grazing management does not constrain voluntary intake. An important aspect of grazing management in this regard is that the height and structure of the pasture is suitable for maximum intake. For perennial ryegrass the optimum height for intake by lambs is $6 \mathrm{~cm}$ whereas for chicory and red clover it is higher, $8 \mathrm{~cm}$, due to their different morphological structure. Grazing management also needs to be used to maximise the leaf to stem ratio.

\section{Agronomic concerns}

However, the advantages of these high feeding value forage species needs to be balanced against any potential disadvantages when developing a pastoral livestock system. Potential disadvantages that need to be managed include: seasonal growth pattern, poor persistence, risk of establishment failure and poorly understood grazing management requirements.

The seasonal growth pattern of white clover, red clover, chicory and plantain varies but they are all dormant or semidormant in winter. Nevertheless, from spring to autumn a combined herb and legume pasture was shown to produce as much dry matter, or more, than the annual production of a traditional perennial ryegrass and white clover pasture (Goh \& Bruce, 2005). In the Manawatu region of New Zealand where the annual production of ryegrass and white clover based pastures is $12 \mathrm{t} \mathrm{DM} / \mathrm{ha}$, the annual production for chicory ranges from 9-14 t DM/ha (Li \& Kemp, 2005; Powell et al., 2007) for plantain its $17 \mathrm{t} \mathrm{DM/ha} \mathrm{(Powell} \mathrm{et} \mathrm{al.,}$ 2007), for white clover ranges from 7-10 t DM/ha, and for red clover from 11-15 t DM/ha (Hyslop, 1999). Therefore, a pastoral system based on legume and herb forage species requires a proportion of its area to be in winter growing forages such as Italian ryegrass or perennial ryegrass and white clover. Twenty per cent of the pasture area in winter growing forage would feed the livestock for the three months of winter and would provide the opportunity for a five year pasture renewal programme within the system. Alternatively, legume and herb forage species could be used on $10-20 \%$ of a pastoral system for specific roles such as finishing summer lambs, increasing the live weight and condition of ewe hogget's or increasing ewe milk production and lamb survival.

In the Wairarapa region of New Zealand which has colder winters and drier summers than the Manawatu birdsfoot trefoil (Lotus corniculatus L.) was found to have the same production as a ryegrass and white clover pasture over three years (Ramirez-Restrepo et al., 2005). The seasonal growth pattern of the two pasture types was different but again a combination of the two would provide a system with year round production and a high feeding value pasture from spring to autumn. The high lamb growth rate possible on birdsfoot trefoil is shown in Table 2. The evidence suggests that it is possible to obtain similar, or greater, annual dry matter production from legume and herb forage species as from ryegrass and white clover pasture, but pastoral systems need to be designed to ensure their different seasonal growth patterns are complementary.

The combination of chicory, plantain, red clover and white clover provides a pasture with a longer growing season than any one of the species by itself. Plantain begins its growth earlier in spring than the other species and chicory and red clover remain more productive as the soil dries out in summer than plantain and white clover.

The persistence as fully productive pastures of the legume and herb species discussed so far ranges from two to five years depending on the weather, management and species (Li \& Kemp, 2005). Although perennial ryegrass and white clover pastures are often perceived as permanent or only needing replacing every 10 years the agronomic research on their productivity suggests it declines after three to five years (Sanderson \& Webster, 2009) and that it is difficult to maintain a white clover percentage above $10 \%$ (Brock \& Hay, 2001) over the lifetime of a pasture. To have pastures producing at their potential in terms of herbage mass and feeding value requires pasture renewal approximately every five years which contrasts with the 2 $\%$ rate of pasture renewal on New Zealand sheep and beef farms (Sanderson \& Webster, 2009).

An attribute in common for many legume and herb species is a tap root. The health and carbohydrate storage of tap roots influences the persistence of these species but it also confers a degree of drought tolerance through accessing water deeper in the soil profile, and an increased capacity to uptake some mineral nutrients (e.g., Cu, Zn, Ca) relative to grass roots. Grazing management needs to consider the renewal of the tap root and to avoid damage when the soil is wet in autumn and winter (Li \& Kemp, 2005). The principles of grazing management for tap rooted plants have been well elucidated through research on alfalfa, red clover and chicory in particular (Lodge, 1991; Li \& Kemp, 2005). The key principles are to not graze into the crown and to use a rotation that maintains tap root size and initial growth of the next generation of shoots. In practice this translates into not grazing below approximately $5 \mathrm{~cm}$ and 
using a rotation based on early flowering or approximately 3-6 weeks for many tap rooted forage species. Recovery of root reserves is more sensitive to grazing frequency than grazing intensity (Li \& Kemp, 2005).

Similarly, the tap root of establishing seedlings needs to be allowed to develop to the size required so it can support survival of the seedling after the first grazing. Although most of the legume and forage species discussed here germinate and develop quickly the first grazing needs to be delayed until approximately six leaves have appeared to ensure the tap root can support the recovery of the establishing plant (Powell et al., 2007). For example, Powell et al. (2007) showed that the survival of chicory seedlings was $69 \%$ when first grazed at 4.8 leaves/plant compared with $84 \%$ when first grazed at 6.6 leaves/plant.

\section{Systems evaluation}

The complete technology package of multiple bearing ewes, high feeding value forage species, seasonal feed planning, and establishment and grazing management of the forage species has the potential based on current research to substantially increase lamb growth rates, hogget mating weights and ewe milk production. The use of forage species with tap roots also has the potential to provide better forage production when rainfall is low and to take up minerals from deeper in the soil than shallower rooted species.

\section{Final Considerations}

Although, component research on sheep and cattle production, and forage production and nutritive value of a herb and legume pasture strongly suggests farmers should adopt this technology it has not been conclusively shown to improve financial, production and environmental outcomes for farmers when used in a pastoral livestock system. It is usual for farmers and their advisors to be provided with component research which they are then expected to incorporate into their system. However, this results in a trial and error approach with no statistical robustness, so often the approach is averse to risk or inadequately monitored and measured to fully ascertain the value of the new system. We suggest that as a result currently available technology packages such as the one described here are not always fully implemented by farmers in a manner that extracts the greatest benefits. We propose to compare fully self-contained livestock systems over three years based on the herb and legume pastures using replication and sufficient measurements of production and environmental factors to comprehensively compare systems using herb and legume pastures with traditional ryegrass and white clover systems. Although these types of experiments are expensive they are essential if advanced technology packages are to be fully adopted by farmers of pastoral livestock systems.

\section{References}

BARRY, T.N. The feeding value of chicory (Chichorium intybus) for ruminant livestock. Journal of Agricultural Science, v.131, p.251-257, 1998.

BLUETT, S.J.; HODGSON, J.; KEMP, P.D. et al. Performance of lambs and the incidence of stagger and heat stress on two perennial ryegrass (Lolium perenne) cultivars using a leaderfollower rotational grazing management system. Journal of Agricultural Science, v.136, p.99-110, 2001.

BROCK, J.L.; HAY, M.J.M. White clover performance in sown pastures: a biological/ecological perspective. Proceedings of the New Zealand Grassland Association, v.63, p.73-83, 2001.

CLARK, D.A.; ANDERSON, C.B.; HONGWEN, G. Liveweight gain and intake of Friesian bulls grazing 'Grasslands Puna' chicory (Cichorium intybus L.) or pasture. New Zealand Journal of Agricultural Research, v.33, p.219-224, 1990.

FRASER, M.D.; SPEIJERS, M.H.M.; THEOBALD, V.J. et al. Production performance and meat quality of grazing lambs finished on red clover, lucerne or perennial ryegrass swards. Grass and Forage Science, v.59. p.345-356, 2004.

FRASER, T.J.; COSGROVE, G.P.; THOMAS, W.J. et al. Performance of Grasslands Puna chicory. Proceedings of the New Zealand Grassland Association, v.49, p.193-196, 1988.

FRASER, T.J.; ROWARTH, J.S. Legumes, herbs or grass for lamb growth. Proceedings of the New Zealand Grassland Association, v.58, p.49-52, 1996.

GOH, K.M.; BRUCE, G.E. Comparison of biomass production and biological nitrogen fixation of multi-species pastures (mixed herb leys) with perennial ryegrass-white clover pasture with and without irrigation in Canterbury, New Zealand. Agriculture Ecosystems \& Environment, v.110, p.230-240, 2005.

GOLDING, K.P.; KEMP, P.D.; KENYON, P.R. et al. High weaned lamb live weight gains on herbs. Agronomy New Zealand v.38, p.33-39, 2008.

HYSLOP, M.G. Evolution of vegetatively reproductive red clovers (Trifolium pratense $L$.) for use in pastoral systems. 1999. Unpublished PhD, Massey University, New Zealand, 1999.

KERR, P. A guide to improved lamb growth 400 Plus. New Zealand Sheep Council, 2000. p.160.

LI, G.; KEMP, P.D. Forage chicory (Cichorium intybus L.): A review of its agronomy and animal production. Advances in Agronomy, v.88 p.187-222, 2005.

LINDSAY, C.L.; KEMP, P.D.; KENYON, P.R. et al. Summer lamb finishing on forage crops. Proceedings of the New Zealand Society of Animal Production, v.67, p.121-125, 2007.

LODGE, G.M. Management practices and other factors contributing to the decline in persistence of grazed lucerne in temperate Australia: A review. Australian Journal of Experimental Agriculture, v.31 p.713-724, 1991.

MARLEY, C.L.; FRASER, M.D.; FYCHAN, R. et al. Effect of forage legumes and anthelmintic treatment on the performance, nutritional status and nematode parasites of grazing lambs. Veterinary Parasitology, v.131, p.267-282, 2005.

MOORHEAD, A.J.E.; JUDSON, H.G.; STEWART, A.V. Liveweight gain of lambs grazing 'Ceres Tonic' plantain (Plantago lanceolata) or perennial ryegrass (Lolium perenne). Proceedings of the New Zealand Society of Animal Production, v.62, p.171-173, 2002. 
NICHOLAS, P.K.; KEMP, P.D.; BARKER, D.J. Stress and recovery of hill pastures in the North Island of New Zealand. Grass and Forage Science, v.59, p.50-26, 2004.

PARSONS, A.J.; NEWMAN, J.A.; PENNING, P.D. et al. Die preference of sheep: effects of recent diet, physiological state and species abundance. Journal of Animal Ecology, v.63, p.465-478, 1994

POWELL, A.M.; KEMP, P.D.; JAYA, I.K.D. et al. Establishment, growth and development of plantain and chicory under grazing. Proceedings of the New Zealand Grassland Association, v.69, p.41-45, 2007.

RAMIREZ-RESTREPO, C.A.; BARRY, T.N.; POMROY, W.E. et al. Use of Lotus corniculatus containing condensed tannins to increase summer lamb growth under commercial dryland farming conditions with minimal anthelmintics drench input. Animal Feed Science and Technology, v.122, p.197-217, 2005.

RAMIREZ-RESTREPO, C.A.; KEMP, P.D.; BARRY, T.N. et al. Production of Lotus corniculatus L. under grazing in a dryland farming environment. New Zealand Journal of Agricultural Research, v.49, p.89-100, 2006.

SANDERSON, K.; WEBSTER, M. Economic analysis of the value of pasture to the New Zealand economy. Report to Pasture Renewal Charitable Trust. Wellington: BERL, 2009. p.42.

SCALES, G.H.; KNIGHT, T.L.; SVAILLE, D.J. Effect of herbage species and feeding level on internal parasites and production performance of grazing lambs. New Zealand Journal of Agricultural Research, v.38, p.237-247, 1995.

WAGHORN, G.C.; BURKE, J.L.; KOLVER, E.S. Principles of feeding value. s.l: New Zealand Society of Animal Production, 2007. p.309. (Occasional Publication, 14).

WAGHORN, G.C.; TAVENDALE, M.H.; WOODFIELD, D.R. Methanogenesis from forages fed to sheep. Proceedings of the New Zealand Grassland Association, v.64, p.167-171, 2002.

WILSON, E. Summer lamb finishing on high-quality permanent sward mixes. 2009. BSc Honours thesis, Massey University, New Zealand, 2009. 